\title{
Analysis of Ideological and Political Education Improvement in the Domain of Internet
}

\author{
Yinwei $\mathrm{Li}^{1}$, Jin $\mathrm{Gao}^{2}$ \\ 1.Political Affairs Office, Xi'an Medical University, Xi'an 710021 China \\ 2.Clinical Medical College, Xi'an Medical University, Xi'an 710021 China
}

\begin{abstract}
Keywords: in the domain of Internet; ideological and political education; exploration for improvement.
\end{abstract}

\begin{abstract}
With the development of the Internet, it is has become an era characterized by the development of network technology, which has greatly changed students' emotional attitudes and ideological concepts. Therefore, under the influence of Internet domain, the requirement to relevant personnel for ideological and political education are becoming higher and higher. In this context, it is extremely necessary to strengthen research on ideological and political education. In this paper, this author analyzed the status quo of ideological and political education in the domain of the Internet and put forward measures for its improvement.
\end{abstract}

\section{Introduction}

Under the influence of the development of the Internet, the ideological and political education in China has ushered in new opportunities for development and also faces a great deal of teaching difficulties, which seriously affects the cultivation of students' values. In the concrete process of ideological and political education, it is necessary to analyze the current situation of ideological and political education under the network vision and give students the correct guidance to help them establish a correct concept and promote the improvement of their ideological and political quality. Therefore, it is imperative to conduct research on the improvement of ideological and political education in the domain of Internet.

\section{Analysis of the Status Quo of Ideological and Political Education in the Domain of Internet}

\subsection{Lack of Advanced Education Methods}

In the ideological and political education in the past, the education method generally used in the classroom was teacher explaining while students listening. This education method can help the teacher to understand students' learning situation in time and also helps to make temporary changes to the teaching content according to the actual situation, and thus it has good flexibility and feedback effects. However, the previous education methods put forward many requirements on the overall quality of teachers. For example, the prepared teaching content, teaching method and personal charisma all need to be of interest to students. Otherwise, the teaching will become boring and students cannot absorb teaching contents well. Teachers can take the advantage of Internet to update the content and expression forms to inspire students' attention.

\subsection{Problems in the Whole Process and Methods of Ideological and Political Education}

The Internet has helped the circulation of information and the amount of information that students are exposed to has gradually increased. In order to promote the effective promotion of teaching effectiveness, teachers engaging in the teaching ideological and political courses must understand the active information in the Internet. The teaching content of the ideological and political curriculum should not only have basic theoretical knowledge, but also include the derivative content of teaching. On this basis, teachers should pay attention to maintaining the authority of theoretical knowledge itself to improve the effectiveness of ideological and political education. However, the main problem at present is that the ideological and political education is generally limited by assigned class hours, while the total amount of teaching work and teaching contents are increasing. And as a result, 
teachers need to continuously innovate in the teaching process and teaching methods to achieve better teaching effects. This is an important element challenging the overall process and methods of ideological and political education at this stage.

\subsection{Outdated Channel of Educational Information}

With the advent of the Internet age, the speed and frequency of the information dissemination has increased, which leads to a fact that information has great space for its development in both universality and timeliness. In the past, mass media mainly relied on paper media, television and radio, but this means of communication has long been unable to adapt to the development of society under the influence of social progress. Teachers need to make use of the Internet in the new era to achieve effective ideological and political education.

\subsection{Complicated Ideological System of Students}

Thanks to that information can be communicated and shared conveniently and quickly through Internet, students in most schools can use the Internet to search and receive information. Some information can broaden students' horizons to a certain extent and also inject new elements into their thinking at the same time. Basically speaking, the more information a student gets from the Internet and the more complex the content of the information he acquires, the greater the impact on the shaping of his own ideas. For example, mixed ideas such as pacifism and personal heroism directly affect the students' own ideological system. If the ideological value of a student has been shaped, it will be difficult to change it through the ideological curriculum.

\section{Measures to Improve Ideological and Political Education in the Domain of Internet}

\subsection{To Strengthen the Optimization of the Contents and Methods of the Ideological and Political Education}

The development of the ideological and political curriculum has very matured theories as well as novel forms. In the domain of Internet, the information-bearing method of ideological and political education is very flexible and diverse. And meanwhile, the improvement of carriers, teaching contents and teaching methods can promote the interest and timeliness of ideological and political education. Therefore, the implementation of the ideological and political curriculum must be combined with the advantages of the network to strengthen the basic theory and application theory of the curriculum, so as to achieve new breakthroughs in the basic knowledge of the ideological and political curriculum as far as possible. It is necessary to learn mature models of other schools and optimize educational theories and practical topics to integrate more teaching materials into the teaching process of the ideological and political education. Teachers should also deepen the connotation of the course contents and integrate advanced relevant research results in into the theoretical teaching. For example, teachers can use related solicit articles or essays and educational lectures to enhance the students' ideological and political education or tell students about the hot issues on the network and guide them to carry out deep exchange of opinions in this process.

\subsection{To Strengthen the Innovation of Ideological and Political Teaching Ideas}

In the field of Internet, schools should apply and build new media technologies based on the full understanding of the advantages of the Internet. The use of network technology and communication technology will help create a system of ideological and political education system and liaison mechanism of media, promoting the integration of network technology into ideological and political education. Afterwards, the schools can innovate in the ideological and political education model and formulate the teaching plan for quality-oriented education closely relying on the network. It is also needed to build a media platform for ideological and political education to develop online education. In the teaching process, it is needed to establish an open teaching philosophy and avoid guiding students' values with the teaching concepts like value neutrality and thought freedom. Instead, teachers are supposed to display students' subjective status in the whole process of ideological and political education and fully utilize the mobility and interactivity of the network, based on the student-oriented concept. The MOOC (Massive Open Online Courses) can be used to cultivate students' own information thinking, promote the effectiveness of teaching and enhance the interest. 
At the same time, it is needed to closely integrate the direction of ideological and political education with students' ideological dynamics, vigorously disseminate positive energy on the schools' Internet platform, and encourage and guide students to understand ideological education through the Internet. It is necessary to grasp the significance of national policies and ideological and political education for personal growth and development, and to promote the improvement of students' ideological and political quality through MOOC as well as ideological and political education activities.

\subsection{To Promote the Improvement of the Overall Quality of Teachers}

With the development of the Internet age, the workload and teaching contents of the ideological and political curriculum are increasing, and the requirements for the overall quality of related teachers are also increasingly strict. To improve the teaching quality of ideological and political education in the domain of the Internet, teachers engaged in ideological and political courses must meet the following two requirements. On the one hand, these teachers must have solid theoretical knowledge. In the actual teaching process, most teachers teaching the ideological and political courses do not have a deep understanding of the theoretical knowledge of this curriculum. As a result, they cannot effectively grasp the teaching difficulties and teaching priorities of the courses and may be not able to effectively solve students' doubt and queries, which leads to the effectiveness and efficiency decline of ideological and political teaching. On the other hand, the teachers engaged in ideological and political curriculum must strengthen their study of the spirit of the times and cultural information. In the era of the Internet, the dissemination speed of spiritual and cultural information is continuously increasing and in turn there are many new ideological and political curriculum theories constantly being formed. These teachers need to understand the theories in depth and use them as a basis to find out measures for implementing the ideological and political education. Only when teachers and students can receive information from society in a parallel way can ideological and political education be conducted more quickly and steadily.

\subsection{To Enhance the Interactivity Between the Teacher and Students}

In the process of implementing education, teachers of ideological and political courses need to strengthen the interaction with students, so as to ensure the effectiveness of the curriculum. Ideological and political education can be a virtuous circle on this basis. In the context of network development, students generally have a strong sense of independence and freedom. Therefore, when carrying out ideological and political education, teachers should fully understand the Internet, inspire students' own attractiveness, and then make use of the convenient conditions provided by network to strengthen communication with students and get close to them. It is also needed to apply the complementarity and similarity in values, worldviews and hobbies, with the purpose to maintain a high level of interactivity with students. On this basis, if the teachers can transform the boring and preaching approach into rich and interesting interactions, they will better integrate the ideological and political education into students' lives through the Internet, which will enable students to accept it more easily.

\subsection{To Improve the Traditional Ideological and Political Teaching Path with the Help of Network}

The ideological and political education in colleges and universities is an important part which can enable students to have a good ideological quality, and thus it is very important for their present study and even work in the future. The ideological impact that the Internet age brings to the students at this stage is enormous, which not only contains positive energy but also covers negative emotions. However, college students are weak in handling matters of such kind and vulnerable to negative influences, thus forming bad ideas. Therefore, colleges and universities must pay enough attention to ideological and political education. In the process of carrying out ideological education for students, it is necessary to fully exploit the characteristics and advantages of network, so as to develop humanistic ideological education according to their actual situation. Specifically, it can be started from two aspects: First of all, some indoctrination ways like starting from the latest online incidents and using concealed and indirect methods can make undergraduates unconsciously influenced by subtle influences, making them have richer ideological and moral connotations. For example, colleges and universities can guide students to conduct in-depth explorations of hot events on the 
Internet by various forms such as classroom discussions, lectures and essays, and it is also needed to encourage them to exchange opinions with and obtain inspiration from each other, so that they can continue to rigorously demand themselves. Secondly, the construction of ideological and political education themed websites can ensure the comprehensiveness of ideological and political education. The value of the Internet itself has been greatly recognized by college students, and in particular, positive events on the Internet have a certain role in promoting the development of college students' ideas. If ideological and political education in colleges and universities can be combined properly with these kinds of events, it will surely achieve excellent teaching results, which will promote the teaching and achieve the desired results. Therefore, universities need to build a themed education website of their own. In the design process, it is necessary to start with the actual situation of college students in line with their psychological characteristics and appeals. Only in this way can ideological and political education be linked to the modern network to help students form a good ideological and political concept by relying on the advantages of the network to achieve the best educational results.

\subsection{To Strengthen the Creation of Teaching Situations to Stimulate Students' Interest}

It can be seen from the ideological and political textbooks that the ideological and political education is supported by rich theories. For example, Marxism-Leninism, Mao Zedong Thought and Deng Xiaoping Theory all attach great importance to ideological education. However, many of these theories are composed of boring words. In the past ideological and political education, teachers generally applied the "duck-stuffing" type of teaching in the ideological and political courses to indoctrinate the students with knowledge in books and textbooks. They did not pay attention to the students' own interest in learning, which was unfavorable for students to form their own thinking skills. The development of Internet has effectively improved this situation. It is feasible for teachers to use the Internet to create teaching situations that suit the curriculum, and then stimulate students' interest in learning. The teaching content of Mao Zedong Thought is taken as an example here. Before teaching, the teacher can do an in-depth research on teaching materials and conduct a comprehensive analysis of teaching contents. Then, the teacher must download the relevant materials through the Internet and make teaching courseware, combining with his own analysis of teaching contents and understanding of the students. In the teaching process, the teacher should be good at using the courseware. Taking the explanation of the "16-word guideline for guerrilla warfare" as an instance, in addition to introducing the relevant video materials in teaching, the teacher should also integrate key knowledge points in class and let students discuss their own views. At the same time, the teacher must create contexts with courseware and explain the background, reasons and effects of the "guideline". All in all, teachers should take full use of the multimedia to blend images, texts and videos with ideological and political knowledge, so as to create a better learning situation, narrowing the distance between ideological knowledge and students.

\section{Conclusion}

All in all, the ideological and political education is deeply affected by the development of Internet, which not only has a certain impact on students' ideological and political quality, but also leads to stagnation or negative impacts on their development. Therefore, it is very necessary to use the Internet to innovate in the teaching contents and methods of the ideological and political curriculum, so that it can advance with the times, obtain better teaching results, improve students' ideological and political quality and ensure the stability of their development. On this basis, it is possible to promote the improvement of the quality of ideological and political education in our country and improve students' comprehensive ability. 


\section{References}

[1]. Zhang Xi. Analysis on the Improvement of Ideological and Political Education in Universities in the Perspective of Internet [J]. Economic Outlook of the Bohai Sea, 2017(11):187.

[2]. Li Ye. Research on the Development Path of Ideological and Political Education of Students in Application-oriented Universities [D]. Jilin University, 2017.

[3]. Wu Yu. Research on Cultivation of Postgraduates' Socialist Core Values from the Perspective of Micro-culture [D]. China University of Geosciences, 2017.

[4]. Zhang Shuixin. Research on the Problems of College Students' Ideological and Political Education and Countermeasures from the Perspective of Marxist Human Theory [D]. Hebei Normal University, 2016.

[5]. Li Liang. Research on the Deep Integration of Information Technology and Teaching of Ideological and Political Education [D]. Shanghai University, 2017.

[6]. Pan Qingquan. Research on the Effectiveness of College Students' Ideological and Political Education from the Perspective of Audience Theory [D]. Southwest University of Political Science \& Law, 2016. 